\title{
Apakah Buyback Stock dapat memberikan Keuntungan Tidak Normal saat Pandemi?
}

\author{
Manajemen Keuangan
}

\author{
Mohammad Arridho Nur Amin ${ }^{1 *}$, Bahrain Pasha Irawan ${ }^{2)}$ \\ ${ }^{1)}$ Fakultas Ekonomi dan Bisnis, Universitas Pancasakti Tegal \\ ${ }^{2)}$ Fakultas Ekonomi dan Bisnis, Universitas Sultan Agung Semarang \\ *Email: mohammad.arridho@gmail.com
}

\begin{abstract}
Abstrak
Penelitian ini bertujuan untuk mengetahui apakah terdapat abnormal return saham serta trading volume activity sebelum dan sesudah perusahaan melakukan buyback stock di tengah kondisi pandemi Covid-19. Sampel yang digunakan adalah perusahaan BUMN yang melakukan Buyback Stock saat masa Pademi Covid-19.Penelitian ini menggunakan data sekunder berupa data harga saham perusahaan harian, data volume perdagangan perusahaan harian, serta data saham beredar dari perusahaan-perusahaan BUMN yang terdaftar di Bursa Efek Indonesia. Penghitungan expected return menggunakan metode Market Adjusted Model. Pengujian terhadap hipotesis menggunakan uji beda paired sample t-test. Hasil penelitian ini secara nilai sig.(tailed) abnormal return lebih besar dari 0,05 yaitu 0,092. Hasil uji beda trading volume activity menunjukkan hasil yang serupa, yaitu nilai sig.(tailed) 0,575 lebih besar dari 0,05 .
\end{abstract}

Kata Kunci: Buyback stock, Abnormal Return, Trading Volume Activity, Expected Return, Market Adjusted Model.

\section{PENDAHULUAN}

Perekonomian Indonesia pada kuartal 2 tahun 2020 menurun drastis diakibatkan munculnya virus baru yang menjangkit masyarakat Indonesia saat ini yaitu Coronavirus (CoV) atau nama ilmiahnya yaitu Covid-19, World Health Organization menyatakan Coronavirus $(\mathrm{CoV})$ atau Covid-19 dapat menjangkit saluran nafas manusia, Covid-19 disebut juga sebagai zoonotic yaitu penularannya ditularkan melalui manusia dan/atau hewan sehingga pemerintah menerapkan Pembatasan Sosial Berskala Besar (PSBB) yang membatasi kerumunan serta aktivitas diluar rumah, akibat dari penerapan PSBB tersebut maka baik aktivitas perkantoran, perdagangan, bahkan sekolah dilarang beroperasi. Pada akhirnya Pandemi Covid-19 yang telah menyebar membawa resiko yang sangat buruk bagi perekonomian Indonesia khususnya di sektor pariwisata, perdagangan, dan investasi. Dampak dari Covid-19 juga berimbas ke perusahaan-perusahaan pada semua sektor, baik sektor keuangan, jasa, maupun manufaktur. Tidak terkecuali perusahaan BUMN, perusahaan BUMN juga mengalami dam- 
pak dari Pandemi Covid-19 dengan mengalami penurunan kinerja, BUMN di sektor perbankan sejak awal Pandemi Covid-19 tercatat terjadi kenaikan resiko kredit bermasalah atau nonperforming loan (NPL), perusahaan BUMN yang bergerak pada sektor pariwisata seperti sektor bandara, pelabuhan, kapal feri, dan penerbangan terkena dampak yang sangat besar. Risiko bagai perusahaan BUMN juga bertambah kaena BUMN karya banyak mengandalkan pembiayaan dari bank pelat merah.

Investasi saham dan semua aset keuangan lainnya memiliki dua parameter dasar yakni risiko dan return (Biswas, 2015). Return sendiri dapat berupa return realisasi (actual return) yang telah terjadi dan return ekspektasi yaitu return yang belum terjadi atau return yang diharapkan terjadi dimasa mendatang. Diketahuinya return realisasi (actual return) dan return ekspektasi (expected return) bermanfaat untuk mengetahui abnormal return. Abnormal retu$r n$ bisa bernilai positif maupun negatif, para investor selalu berharap memperoleh abnormal return positif dari investasi yang telah mereka lakukan sebab abnormal return merupakan suatu kelebihan return dari return yang seharusnya terjadi.

BUMN merupakan perusahaan berbentuk perseroan terbatas yang modalnya terbagi dalam saham yang seluruh atau paling sedikit $51 \%$ (lima puluh satu persen) sahamnya dimiliki oleh Negara Republik Indonesia yang tujuan utamanya mengejar keuntungan tujuan dari proporsi saham yang dimiliki oleh saham negara lebih besar dibandingkan saham publik adalah agar pemerintah dapat mengendalikan arah bisnis BUMN. Akibat dari Pandemi Covid-19 di Indonesia, sejumlah perusahaan BUMN kinerjanya merosot tajam, laporan keuangan pada semester 1 tahun 2020 yang dikeluarkan BUMN menunjukkan hasil bahwa kinerja BUMN anjlok diakibatkan Pandemi Covid-19, bahkan hingga mengalami kerugian. Hal tersebut berdampak juga terhadap jatuhnya harga saham perusahaan BUMN di pasar sekunder, sehingga sejumlah BUMN berencana untuk melakukan buyback stock. Berdasarkan protokol krisis OJK dan BEI sudah memiliki aturan bahwa perusahaan diperbolehkan melakukan buyback stock tanpa melalui Rapat Umum Pemegang Saham (RUPS). Aksi korporasi tersebut dilakukan BUMN karena penurunan harga saham perusahaan pelat merah melebihi fundamental, saham yang dibeli kembali tersebut dilakukan secara bertahap serta nantinya akan ditempatkan di treasury stock.

Dengan adanya PSBB yang diterapkan di berbagai wilayah khususnya di Jakarta, maka perkantoran dan sebagian besar industri dilarang beroperasi pada kurun waktu yang relatif lama, dilarangnya operasional perusahaan tersebut mengakibatkan kerugian ekonomi 
khususnya bagi perusahaan BUMN di berbagai sektor. Atas dasar tersebut dilakukannya buyback stock yang diharapkan dapat memperkuat IHSG serta membantu stabilitas harga saham perseroan di Bursa Efek Indonesia juga mengurangi dampak dampak pasar modal yang berfluktuasi signifikan.

\section{Kajian Pustaka}

\section{Badan Usaha Milik Negara (BUMN)}

Undang-undang Nomor 19 Tahun 2003 Tentang Badan Usaha Milik Negara, yang selanjutnya disebut BUMN adalah badan usaha yang seluruhnya atau sebagian besar modalnya dimiliki oleh Negara melalui Penyertaan secara langsung yang berasal dari kekayaan negara yang dipisahkan. Terdapat 4 unsur BUMN yaitu Badan Usaha, Seluruh atau sebagian besar modalnya dimiliki oleh Negara, melalui penyertaan langsung, dan Berasal dari kekayaan Negara yang dipisahkan.

\section{Buyback Stock}

Buyback adalah salah satu bentuk tindakan korporasi yang dilakukan emiten, yaitu untuk menjaga kewajaran harga saham, sebagai sinyal psikologis ke pasar, melakukan pembelian saham yang nantinya akan dijual kembali, serta melakukan pembelian kembali saham untuk dibagikan kepada karyawan (Rusbandi (2009)..

\section{Abnormal Return Saham}

Jogiyanto (2013), menjelaskan bahwa abnormal return merupakan kelebihan dari return yang sesungguhnya terjadi terhadap return normal yang merupakan return yang diharapkan oleh investor (expected return). Abnormal return merupakan selisih dari return yang sesungguhnya (actual return) dengan return yang diharapkan (expected return), (Robert Ang, 1997). Tingkat return yang sesungguhnya (Rit) merupakan perbandingan antara selisih harga saham periode sekarang dengan periode sebelumnya secara relatif. Tingkat keuntungan yang diharapkan (Rmt) merupakan perbandingan IHSG periode sekarang dengan periode sebelumnya.

Abnormal return dapat dicari dengan menggunakan model Market Adjusted Model (Brown dan Warner 1985) sebagai berikut:

$$
\text { Arit }=\text { Rit }- \text { Rmt }
$$


`Abnormal return yang positif mengindikasikan bahwa tingkat keuntungan yang diperoleh lebih besar antara actual return dengan expected return. Berkaitan dengan buyback stock, abnormal return yang positif setelah buyback stock dapat memberikan keuntungan diatas normal untuk investor, dan juga sebaliknya, jika abnormal return setelah buyback stock menunjukkan negatif mengindikasikan bahwa keuntungan yang didapat oleh investor dibawah normal.

\section{Trading Volume Activity}

Aktifitas volume perdagangan merupakan gambaran tentang kondisi dari efek yang diperjual belikan di pasar modal. Besarnya volume perdagangan dapat diketahui dengan mengamati kegiatan perdagangan saham melalui indikator yaitu likuiditas saham yang diukur dengan aktivitas volume perdagangan (Trading Volume Activity). Trading volume activity adalah suatu indikator yang dapat digunakan untuk melihat reaksi pasar terhadap suatu informasi melalui parameter volume perdagangan saham di pasar modal. Hal tersebut dikarenakan TVA berbanding lurus dengan likuiditas saham, semakin tinggi nilai TVA suatu saham maka mempunyai makna bahwa saham tersebut dapat dijual dengan mudah karena investor memiliki keinginan membeli saham tersebut dengan kata lain saham tersebut memiliki tingkat likuiditas yang tinggi. Jika TVA semakin besar maka saham semakin likuid, sebaliknya jika TVA semakin kecil maka saham tersebut tidak likuid. (Panjaitan: 2013).

Volume perdagangan saham mencerminkan kekuatan antara penawaran dan permintaan yang merupakan cerminan dari tingkah laku investor (Robert Ang, 1997). Kenaikan tingkat volume perdagangan merupakan cerminan kenaikan aktivitas jual beli para investor terhadap saham. Semakin tinggi volume penawaran dan permintaan suatu saham perusahaan, maka semakin besar juga dampaknya terhadap fluktuasi harga saham perusahaan di bursa, dan semakin meningkatnya volume perdagangan saham menunjukkan semakin diminatinya saham perusahaan tersebut oleh masyarakat sehingga akan membawa pengaruh positif terhadap naiknya harga dan berdampak terhadap return saham.

Secara matematis Trading Volume Activity (TVA) dapat dirumuskan sebagai berikut:

$$
\text { TVA }=\frac{\text { Jumlah Saham yang diperdagangkan }}{\text { Jumlah Saham yang Beredar }}
$$

Trading Volume Activity adalah rasio antara jumlah lembar saham yang diperdagangkan pada waktu tertentu terhadap jumlah saham yang beredar pada waktu tertentu. Jumlah 
saham yang diterbitkan merupakan jumlah lembar saham saat perusahaan tersebut melakukan emisi saham.

\section{Signaling Theory}

Signalling Theory merupakan sebuah teori yang menjelaskan bahwa terjadinya buyback stock disebabkan karena perusahaan menilai bahwa emiten perlu mengeluarkan kebijakan berupa buyback stock karena saham yang ditawarkan dan diperjual-belikan di bursa saham sesudah kegiatan buyback stock (pemecahan saham) merupakan saham yang layak dan bagus, dan juga mempunyai laporan keuangan yang baik atau stabil secara fundamental, serta memiliki pergerakan saham yang semakin mahal dan signifikan secara teknikal (analisis teknikal) yang diikuti nilai BV (Book Value) yang semakin meningkat serta memilki PBV (Price Book Value) yang tinggi, yang dibuktikan dengan harga saham yang semakin tinggi, sehingga memberikan sinyal kepada investor serta trader saham, bahwa saham yang sudah dilakukan buyback stock berdasarkan signalling theory mempunyai peluang profit (keuntungan) yang tinggi.

\section{Perbandingan Abnormal Return Sebelum dan Sesudah Buyback Stock}

Perusahaan BUMN yang melakukan Buyback stock dapat artikan bahwa perusahaan tersebut menginformasikan mengenai perusahaan tentang adanya prospek yang bagus dimasa mendatang, dimana harga saham yang tinggi merupakan salahsatu indikator bahwa kinerja perusahaan bagus. Marwata (2000) menyatakan bahwa harga saham yang menjadi lebih murah menyebabkan banyaknya transaksi yang akan dilakukan sehingga harga saham sering berubah dan dapat memberikan peluang untuk memperoleh abnormal return bagi investor. Abnormal return akan dihitung dengan menghitung selisih dari actual return dan expected return, dimana actual return adalah perbandingan dari harga saham hari ini dengan harga saham sebelumnya secara relatif. Sedangkan expected return dihitung dengan menghitung return pasar yang diperoleh dari selisih IHSG hari ini dengan IHSG sebelumnya. Bila $a b$ normal return saham yang diperoleh setelah melakukan buyback stock terjadi penurunan, maka akan berakibat pada abnormal return yang diperoleh bernilai negatif karena actual return yang diperoleh lebih rendah dibanding expected return. Berdasarkan uraian diatas maka dapat diperoleh hipostesis yaitu :

H1 : Terdapat perbedaan abnormal return saham yang signifikan pada periode sebelum dan sesudah buyback stock.

\section{Perbandingan Trading Volume Activity Sebelum dan Sesudah Buyback Stock}


Trading Volume Activity merupakan salah satu indikator yang digunakan untuk melihat reaksi pasar atas peristiwa ataupun informasi yang berkaitan dengan suatu saham perusahaan. Perubahan volume perdagangan saham diukur dengan aktivitas volume perdagangan saham yang diukur dengan menggunakan Trading Volume Activity (TVA). TVA merupakan perbandingan antara jumlah saham yang diperdagangkan pada waktu tertentu dengan jumlah saham perusahaan yang beredar pada periode tertentu. Besar kecilnya perubahan rata-rata TVA antara sebelum dan sesudah terjadinya buyback stock merupakan ukuran besar kecilnya akibat yang ditimbulkan oleh adanya buyback stock terhadap volume perdagangan saham. Ketika harga saham perusahaan dinilai terlalu tinggi maka buyback stock menjadi salah satu cara perusahaan agar dapat meghimpun dana dari masyarakat. Jika harga suatu saham di nilai terlalu tinggi maka nantinya akan mempengaruhi kemampuan investor untuk membelinya. Besar kecilnya pengaruh dari buyback stock terhadap volume perdagangan saham terlihat dari besar kecilnya jumlah saham yang diperdagangkan (Copeland, 2002).

Harga saham menjadi lebih rendah saat perusahaan melakukan buyback stock sehingga volatilitas harga saham menjadi lebih besar dan akan menarik minat investor untuk memiliki saham tersebut atau menambah jumlah saham yang diperdagangkan. Menurut Copeland (2002), semakin banyak investor yang akan melakukan transaksi terhadap saham tersebut maka volume perdagangan sahamnya akan meningkat. Berdasarkan uraian diatas maka dapat diperoleh hipostesis yaitu :

H2 : Terdapat perbedaan trading volume activity saham yang signifikan pada periode sebelum dan sesudah buyback stock.

\section{METODE PENELITIAN}

\section{Variabel Penelitian}

Data yang digunakan untuk kedua vadiabel penelitian adalah data sekunder, yaitu data saham harian perusahaan BUMN saat pelaksanaan buyback stock, volume saham harian, dan data saham beredar perusahaan BUMN sehingga menghasilkan data abnormal return dan trading volume activity. Data sekunder diperoleh dengan menggunakan metode pengamatan saham-saham BUMN selama masa pandemi yaitu selama periode buyback stock tahun 2020.

Penelitian ini menggunakan beberapa data yaitu tanggal pengumuman buyback stock perusahaan BUMN, harga saham penutupan harian perusahaan BUMN yang melakukan buyback stock, jumlah saham yang diperdagangkan secara harian, dan jumlah saham yang beredar atau listed share yang diambil www.idx.co.id 
Tabel 1. Daftar Perusahaan BUMN yang Menjadi sampel akhir Penyaringan Sampel Awal

\begin{tabular}{ccc} 
No & Kode Perusahaan & Tanggal Buyback Stock \\
\hline 1 & WSKT & 12 Maret 2020 \\
\hline 2 & BBRI & 13 Maret 2020 \\
\hline 3 & PTPP & 13 Maret 2020 \\
\hline 4 & WIKA & 13 Maret 2020 \\
\hline 5 & BBNI & 16 Maret 2020 \\
\hline 6 & BMRI & 20 Maret 2020 \\
\hline 7 & PTBA & 17 Maret 2020
\end{tabular}

Sumber : data sekunder diolah

Tabel 2. Klasifikasi Perusahaan

Berdasarkan Sektor Industri

\begin{tabular}{ccc}
\hline No & Kode Perusahaan & Sektor \\
\hline 1 & WSKT & $\begin{array}{c}\text { Property, Real Estate and Building } \\
\text { Construction }\end{array}$ \\
\hline 2 & BBRI & $\begin{array}{c}\text { Finance } \\
\text { PTPP }\end{array}$ \\
\hline 3 & $\begin{array}{c}\text { Property, Real Estate and Building } \\
\text { Construction }\end{array}$ \\
\hline 4 & WIKA & $\begin{array}{c}\text { Property, Real Estate and Building } \\
\text { Construction }\end{array}$ \\
\hline 5 & BBNI & Finance \\
\hline 6 & BMRI & Finance \\
\hline 7 & PTBA & Mining \\
\hline
\end{tabular}

Sumber : data sekunder diolah

\section{Alat Analisis dan Pengujian Hipotesis}

Uji Normalitas data dilakukan sebelum melakukan uji beda terhadap variabel abnormal return dan trading volume activity, hal tersebut dilakukan untuk mengetahui apakah ada data yang terdistribusi tidak normal. Pengujian normalitas data akan dilakukan dengan uji statistik kolmogrov-smirnov, apabila tingkat signifikansi lebih dari 5\% atau 0,05 maka data tersebut terdistribusi normal, namun sebaliknya jika tingkat signifikansi kurang dari $5 \%$ atau 0,05 maka data tersebut terdistribusi tidak normal dan akan diuji menggunakan uji wilcoxon signed rank test. 


\section{Uji Beda}

Uji beda dilakukan untuk membuktikan apakah buyback stock mempunyai pengaruh yang signifikan terhadap abnormal return dan trading volume activity pada sebelum dan sesudah dilakukannya buyback stock.

\section{Wilcoxon Signed Ranks Test}

Apabila data berdistribusi tidak normal maka pengujian dilakukan dengan menggunakan pengujian non-parametik yaitu uji wilcoxon signed ranks test. Dasar pengambilan keputusan adalah sebagai berikut :

Jika probabilitas $>0,05$ maka Ha ditolak

Jika probabilitas $\leq 0,05$ maka Ha diterima

\section{HASIL DAN PEMBAHASAN}

\section{Pembahasan Hasil Penelitian}

Tabel 3. Hasil Analisis Deskriptif Statistik

Descriptive Statistics

\begin{tabular}{|l|r|r|r|r|r|}
\hline & N & Minimum & Maximum & Mean & Std. Deviation \\
\hline H_5 & 8 & $-0,06102$ & 0,00563 & $-0,0244475$ & 0,02035097 \\
H_4 & 8 & $-0,13355$ & 0,03253 & $-0,0486513$ & 0,05975159 \\
H_3 & 8 & $-0,08293$ & 0,09538 & $-0,0076075$ & 0,06651972 \\
H_2 & 8 & $-0,08399$ & 0,02370 & $-0,0238113$ & 0,04170174 \\
H_1 & 8 & $-0,13201$ & $-0,01789$ & $-0,0661475$ & 0,04092225 \\
H_0 & 8 & $-0,12003$ & 0,02816 & $-0,0475413$ & 0,06702494 \\
H1 & 8 & $-0,03896$ & $-0,01494$ & $-0,0215088$ & 0,00748072 \\
H2 & 8 & $-0,05687$ & $-0,01696$ & $-0,0259363$ & 0,01470815 \\
H3 & 8 & $-0,04000$ & 0,19031 & 0,0135325 & 0,07737078 \\
H4 & 8 & $-0,09086$ & 0,05752 & $-0,0206563$ & 0,04068494 \\
H5 & 8 & $-0,08923$ & 0,08167 & $-0,0316900$ & 0,05483438 \\
Valid N (listwise) & 8 & & & \\
\hline
\end{tabular}

Sumber: data diolah 2020 
Tabel 3 menunjukkan nilai minimum, maksimum, rata-rata, dan standar deviasi. Waktu H-5 nilai minimum adalah sejumlah -0,06102 didapat oleh perusahaan Bank Mandiri Tbk, dan nilai maksimum adalah sejumlah 0,00563 didapat oleh perusahaan Wijaya Karya Tbk. Rata-rata abnormal return waktu H-5 hari diperoleh bernilai negatif sejumlah -0,0244475 dengan standar deviasi sejumlah 0,02035097.

Waktu H-4 nilai minimum adalah sejumlah -0,13355 didapat oleh perusahaan Bank BNI Tbk, dan nilai maksimum adalah sejumlah 0,03253 didapat oleh perusahaan Bank Mandiri Tbk. Rata-rata abnormal return waktu H-4 hari bernilai negatif sejumlah -0,0486513 dengan standar deviasi sejumlah 0,05975159.

H-3 memiliki nilai minimum sejumlah -0,08293 didapat oleh perusahaan Waskita Karya Tbk, dan nilai maksimum adalah sejumlah 0,09538 didapat oleh perusahaan Bukit Asam Tbk. Rata-rata abnormal return waktu H-3 hari bernilai negatif sejumlah -0,076075 dengan standar deviasi sejumlah 0,06651972.

Lalu pada H-2 nilai minimum adalah sejumlah -0,08399 didapat oleh perusahaan Wijaya Karya Tbk, dan nilai maksimum adalah sejumlah 0,02370 didapat oleh perusahaan Bank BNI Tbk. Rata-rata abnormal return waktu H-2 hari bernilai negatif sejumlah 0,0238113 dengan standar deviasi sejumlah 0,04170174.

Waktu H-1 nilai minimum adalah sejumlah -0,13201 didapat oleh perusahaan Wijaya Karya Tbk, dan nilai maksimum adalah sejumlah -0,01789 didapat oleh perusahaan Bank Mandiri Tbk. Rata-rata abnormal return waktu H-1 hari bernilai negatif sejumlah -0,0661475 dengan standar deviasi sejumlah 0,04092225.

Saat pelaksanaan atau hari $\mathrm{H}$ nilai minimum adalah sejumlah -0,12003 didapat oleh perusahaan Bukit Asam Tbk, dan nilai maksimum adalah sejumlah 0,02816 didapat oleh perusahaan Wijaya Karya Tbk. Rata-rata abnormal return waktu hari $\mathrm{H}$ bernilai negatif sejumlah -0,0475413 dengan standar deviasi sejumlah 0,06702494.

Waktu H+1 nilai minimum adalah sejumlah -0,03896 didapat oleh perusahaan Bukit Asam Tbk, dan nilai maksimum adalah sejumlah -0,01494 didapat oleh perusahaan Bank BRI Tbk. Rata-rata abnormal return waktu $\mathrm{H}+1$ hari bernilai negatif sejumlah -0,0215088 dengan standar deviasi sejumlah 0,00748072. 
Pada $\mathrm{H}+2$ nilai minimum adalah sejumlah $-0,05687$ didapat oleh perusahaan Bank Mandiri Tbk, dan nilai maksimum adalah sejumlah -0,01696 didapat oleh perusahaan Bukit Asam Tbk. Rata-rata abnormal return waktu $\mathrm{H}+2$ hari bernilai negatif sejumlah $-0,0259363$ dengan standar deviasi sejumlah 0,01470815.

H+3 nilai minimum adalah sejumlah -0,04000 didapat oleh perusahaan Wijaya Karya Tbk, dan nilai maksimum adalah sejumlah 0,19031 didapat oleh perusahaan Bukit Asam Tbk. Rata-rata abnormal return waktu $\mathrm{H}+3$ hari bernilai positif sejumlah 0,0135325 dengan standar deviasi sejumlah 0,07737078.

Waktu H+4 hari nilai minimum adalah sejumlah -0,09086 didapat oleh perusahaan Bank BNI Tbk, dan nilai maksimum adalah sejumlah 0,05752 didapat oleh perusahaan Bank Mandiri Tbk. Rata-rata abnormal return waktu $\mathrm{H}+4$ hari bernilai negatif sejumlah 0,0206563 dengan standar deviasi sejumlah 0,04068494.

Lalu pada $\mathrm{H}+5$ hari nilai minimum adalah sejumlah -0,08923 didapat oleh perusahaan Wijaya Karya Tbk, dan nilai maksimum adalah sejumlah 0,08167 didapat oleh perusahaan Bukit Asam Tbk. Rata-rata abnormal return waktu $\mathrm{H}+5$ hari bernilai negatif sejumlah 0,0316900 dengan standar deviasi sejumlah 0,05483438.

Rata-rata abnormal return yang positif adalah didapat pada waktu $\mathrm{H}+3$, Rata-rata abnormal return yang negatif adalah didapat pada waktu H-5, H-4, H-3 H-2, H-1, H0 H+1, $\mathrm{H}+2, \mathrm{H}+4$ dan $\mathrm{H}+5$ hari. Rata-rata abnormal return tertinggi ditemukan pada waktu hari $\mathrm{H}+3$.

\section{Uji Normalitas}

Tabel 4. Hasil Uji Normalitas Abnormal Return

\begin{tabular}{|l|c|c|c|}
\hline \multirow{2}{*}{\multicolumn{2}{|c|}{}} & \multicolumn{2}{|c|}{ Kolmogorov-Smirnov } \\
\cline { 3 - 4 } & Statistic & Sig. \\
\hline \multirow{2}{*}{ Abnormal return } & Sebelum & 0.186 & 0.200 \\
\cline { 2 - 4 } & Sesudah & 0.222 & 0.022 \\
\hline $\begin{array}{l}\text { Trading volume } \\
\text { activity }\end{array}$ & Sebelum & 0.231 & 0.200 \\
\cline { 2 - 4 } & Sesudah & 0.226 & 0.124 \\
\hline
\end{tabular}

Sumber : data diolah spss

Pada tabel 5 menunjukkan variabel trading volume activity berdistribusi normal dimana ditunjukkan dengan nilai Sig. pada semua variabel (sebelum dan sesudah) lebih besar dari 0,05, namun pada pengujian normalitas abnormal return hasil signifikansi data abnormal 
return sesudah pengumuman terdistribusi tidak normal. Sehingga untuk pengujian hipotesis menggunakan wilcoxon rank test.

\section{Uji Beda Wilcoxon Signed Rank Test}

Tabel 5. Hasil Uji Beda Wilcoxon Signed Rank Test

\begin{tabular}{|l|c|c|}
\hline & $\begin{array}{c}\text { Abnormal } \\
\text { Return }\end{array}$ & $\begin{array}{c}\text { Trading Volume } \\
\text { Activity }\end{array}$ \\
\hline $\mathrm{Z}$ & -1.682 & $-0,561$ \\
\hline Asymp. Sig. (2-tailed) & 0,092 & 0.575 \\
\hline
\end{tabular}

Sumber : data diolah spss

\section{Abnormal Return}

Hasil dari pengujian variabel Abnormal Return dengan menggunakan uji beda Wilcoxon Signed Rank Test menunjukkan nilai sig.(tailed) yang lebih besar dari 0,05 $(0,092>0,05)$ yang berarti H0 diterima serta H1 ditolak, atau tidak ada perbedaan antara abnormal return sebelum dan sesudah buyback stock pada perusahaan BUMN yang melakukan buyback stock pada tahap awal.

Dalam masa pandemi ini dimana harga cenderung meningkat dikarenakan PSBB yang dilakukan di beberapa daerah, khususnya di jakarta. Saat diberlakukannya PSBB demi menurunkan penyebaran covid-19 maka semua kegiatan di luar rumah di batasi atau dilakukannya Work From Home (WFH), hal tersebut sangat berdampak terhadap berbagai sektor sehingga pasar belum merespon positif atas dilakukannya buyback stock yang dilakukan perusahaan BUMN. Sehungga berdasarkan uji beda paired sampel t-test yang telah dilakukan menunjukkan bahwa tidak ada perbedaan yang signifikan antara abnormal return sebelum dan sesudah dilakukannya buyback stock.

\section{Trading Volume Activity}

Hasil uji beda Trading Volume Activity dengan menggunakan uji beda paired sampel t-test yang menunjukkan nilai sig. (tailed) yang lebih besar dari $0,05(0,575>0,05)$ yang berarti bahwa $\mathrm{H} 0$ diterima dan $\mathrm{H} 2$ ditolak, atau tidak ada perbedaan antara trading volume activity sebelum dan sesudah buyback stock

Berdasarkan dari hasil uji beda yang telah dilakukan menunjukkan bahwa tidak ada perbedaan yang signifikan antara trading volume activity sebelum dan sesudah buyback stock. Hal ini berkebalikan dengan trading range theory yaitu untuk menempatkan saham pada 
harga yang tepat sehingga dapat menarik calon investor untuk membeli saham dan meningkatkan volume perdagangan saham.

Tidak adanya perbedaan yang signifikan pada trading volume activity sebelum dan sesudah buyback stock, salah satunya dikarenakan pasar belum dapat merespon saat Perusahaan BUMN melakukan buyback stock, hal tersebut dikarenakan pengalihan kebutuhan pada masyarakat dari berinvestasi dialihkan ke simpanan guna memenuhi kebutuhan disaat pemerintah melakukan PSBB, hal tersebut tercermin pada penurunan IHSG dan penurunan volume pembelian saham di berbagai perusahaan, sehingga masyarakat menganggap pengumuman buyback stock bukan sebagai berita baik (good news)

\section{KESIMPULAN, DAN SARAN}

KESIMPULAN

Berdasarkan pembahasan penelitian analisis data maka dapat disimpulkan bahwa buyback stock belum dapat memberikan abnormal return positif dalam pelaksanaan awal buyback stock ini, berdasarkan hasil uji wilcoxon signed rank test terhadap rata-rata abnormal return dan rata-rata trading volume activity pada periode sebelum dan sesudah buyback stock dapat disimpulkan bahwa investor serta masyarakat menilai bahwa adanya pengumuman buyback stock yang dilakukan oleh emiten tidak memberikan sinyal positif bagi investor, serta tidak memberikan perbedaan maupun abnormal return positif maupun trading volume activity.

Salah satu hal yang menyebabkan tidak ada signifikan tersebut adalah karena investor tidak tertarik untuk membeli saham tersebut walaupun saham perusahaan tersebut meiliki prospek yang menjanjikan dikarenakan Persahaan BUMN dapat bertahan di tengah kondisi perekonomian yang menurun dengan tetap dapat melakukan buyback stock sehingga harga saham Perusahaan BUMN tidak terlalu turun. Ketidaktertarikan investor untuk membeli saham perusahaam BUMN dikarenakan peralihan kebutuhan masyarakat di tengah kondisi Pandemi Covid-19, investasi yang dilakukan masyarakat ataupun investor banyak yang di lepas atau di jual kembali, hal ini terjadi di beberapa instrumen investasi seperti emas, tanah, bahkan saham. Hal tersebut dilakukan demi memenuhi kebutuhan di tengah pemberlakuan PSBB yang terjadi di sejumlah daerah. Disamping itu calon investor pun menilai bahwa harga saham masih akan menurun dikarenakan kondisi perekonomian yang masih terus menurun dikarenakan belum ditemukannya solusi dari Pandemi Covid-19 yang tengah terjadi di Indonesia. 


\section{Saran}

Berdasarkan kesimpulan penelitian yang telah di paparkan, beberapa saran dapat diajukan peneliti agar penelitian selanjutnya

Bagi pemegang saham maupun calon investor saham perusahaan BUMN dapat menjadi alternatif pilihan dalam berinvestasi di tengah kondisi pandemi, hal tersebut dikarenakan perusahaan BUMN masih dapat bertahan serta dapat melakukan corporate action. Hal tersebut membuktikan bahwa perusahaan BUMN masih memiliki prospek yang bagus di kemudian hari.

Bagi peneliti selanjutnya, diharapkan dapat meneliti pada beberapa tahap buyback yang dilakukan perusahaan BUMN, sehingga kondisi perusahaan dapat terlihat dengan jelas prospeknya, karena tahap satu pelaksanaan buyback Perusahaan BUMN ini masih belum dapat direspon baik oleh pasar.

\section{DAFTAR PUSTAKA}

Amin, M. A. N. (2020). Apakah Buyback stock Memberikan Keuntungan Tidak Normal?. Permana : Jurnal Perpajakan, Manajemen, Dan Akuntansi, 12(1), 9-17. https://doi.org/10.24905/permana.v12i1.90

Ang, R, 1997. Buku Pintar Pasar Modal Indonesia, Jakarta: Erlangga.

Biswas, Debasish. 2015. The Effect Of Portfolio Diversification Theory: Study On Modern Portfolio Theory Of Stock Investment In The National Stock Exchange. Journal of Commerce \& Management Thought, 6-3, pp: 445-455.

Brown dan J.B Warner, 1985. "Using Daily Stock Return: The Case of Event Studies," Journal of Financial Economics 14. Hal 3-31.

Copeland, T.E., 2002. "Liquidity Changes Following Buyback stocks". The Journal of Finance, Vol. 34, No.1, pp. 115-141.

Hartono, J. 2010. Teori Portofolio dan Analisis Investasi. Edisi Portofolio dan Analisis Investasi. Yogyakarta: BPFE.

Hartono, J. 2013. Teori dan Analisis Investasi. Edisi Kedelapan. Yogyakarta : BPFE.

Horne, Van and Wachowicz, 1997. Prinsip-Prinsip Manajemen Keuangan, Edisi sembilan. Jakarta: Salemba Empat.

Madura, J. 2003. Financial Markets and Institutions. Sixth Edition. South Eestern: Thomson.

Noor, Henry Faizal. 2009. Investasi: Pengelolaan Keuangan Bisnis dan Pengembangan Ekonomi Masyarakat. Jakarta: Indeks. 
Nur, A. M., \& Dadan, R. (2017). Analysis Of Abnormal Return, Stock Return And Stock Liquidity Before And After Buyback Share: Case Study Of Companies Listed In Indonesia Stock Exchange In Period Of 2011-2015. Russian Journal of Agricultural and Socio-Economic Sciences.

Reilly and Brown. 2009. Investment Analysis and Portofolio Management. USA: The Dryden Press Hacouft Brace Collage.The Impact of Share Split for Share Return

Rudnicki, J. 2012. Buyback stocks and Liquidity For Two Major Capital Markets From Central - Eastern Europebusiness. Management And Education, 10 (2), pp: 145-158

Rusbandi, N dan Heykal M. 2009. Pengaruh Buy Back Saham PT Telkom Terhadap Dividen Periode 2005-2008. Jurnal Telkom University. 